\title{
"Tende em vós o mesmo sentimento de Cristo Jesus": a autodoação do discípulo na hermenêutica da esperança cristã
}

\author{
Orientador: Cesar Augusto Kuzma \\ Mestrando: Matheus Leite Tavares \\ Área de Concentração: Teologia Sistemático-Pastoral \\ Linha de Pesquisa: Fé e cultura
}

"Tende em vós o mesmo sentimento de Cristo Jesus" (F1 2,5) é um convite a uma espécie de seguimento ao Ressuscitado. O modelo se encontra explicitado na vida, ministério, morte e ressurreição de Jesus de Nazaré, histórico, pleno em humanidade e divindade, e no modo como se deu a sua kenosis. Este ato de despojamento do Mestre ocorre em vias de revelação, salvação e serviço abnegado a todo aquele que dele necessitar, e no limite de tal necessidade. Além disso, provoca a esperança de que aquilo que ele viveu poderá ser vivido por toda pessoa de fé, anunciando o Reino de Deus como presente e futuro. Aplica-se, aqui, ao esvaziamento o termo "autodoação" a fim de conceituar os aspectos de liberdade e gratuidade desta entrega. Em virtude disso, o seguimento radical, discipulado, ocorre nos mesmos moldes do ofertado pelo Cristo, o discípulo atua em sua própria kenosis com o objetivo de revelar, salvar e servir ao outro. Contudo, tal radicalidade somente se tornará possível pelo assumir uma "ressignificação" da realidade, uma hermenêutica da existência a qual permita viver de modo novo a mesma vida. Esta hermenêutica vem a ser fruto da esperança cristã que, enquanto "força" escatológica, se origina no agir do Filho na história humana e se orienta para ele mesmo. Por isso, se conclui que o agir da esperança, o viver em autodoação, configura-se enquanto paradigma da "cidadania" do Reino de Deus, um viver na radicalidade da entrega na direção do outro, e no limite de sua necessidade.

Palavras-chave: Kenosis. Autodoação. Esperança cristã. 